\title{
COLONEL NEILSON: SALT MERCHANT
}

\author{
By Robert T. Thompson
}

From the large collection of "Neilson Papers" deposited in the Rutgers University Library, Professor Thompson bas extracted a story of the efforts made by the New Fersey patriots to keep the Revolutionary Army supplied with one of the most commonplace and most essential of the sinews of war. Colonel Neilson served as a trustee of Queens College from 1782 until bis death in 1833 . His life is thus intimately connected botb with the founding of the United States and with the early development of Rutgers University.

$\mathbf{N}$

O commodity had a more vital relationship to American colonial life than salt. The preservation of meat and fish products for home use or export markets was dependent on the volume and quality of the salt supply. In the colonial era there were frequent complaints against the restrictions imposed by the British government on salt imports into the colonies, but the comparative advantages of other types of economic enterprise prevented any substantial development of salt manufacture in the continental English colonies.

With the coming of the American Revolution the normal Portuguese and West Indian sources of salt supply were closed to the Thirteen Colonies or else rendered extremely uncertain by the British blockade of American ports. It therefore became imperative for New Jersey and other states in revolt to discover and promote new sources. Failure to do so would not only cripple the operations of the patriot army, ${ }^{1}$ but also jeopardize the health and well-being of American citizens generally.

The New Jersey legislature, prompted by the fear that Great Britain would greatly distress, if not reduce, the state by cutting off its supply of salt, passed a series of private bills to encourage its manufacture. ${ }^{2}$ These bills in general gave

\footnotetext{
1 The army might be dangerously encumbered in its movements if it had to rely on droves of live cattle for its meat supply.

${ }^{2}$ Peter Wilson, compiler, Acts of the Council and General Assembly of New Fersey. Acts of October 5, 1776; March 17, 1777; June 5, 1777; October 7, 1777; December 2, I777; December II, I777.
} 


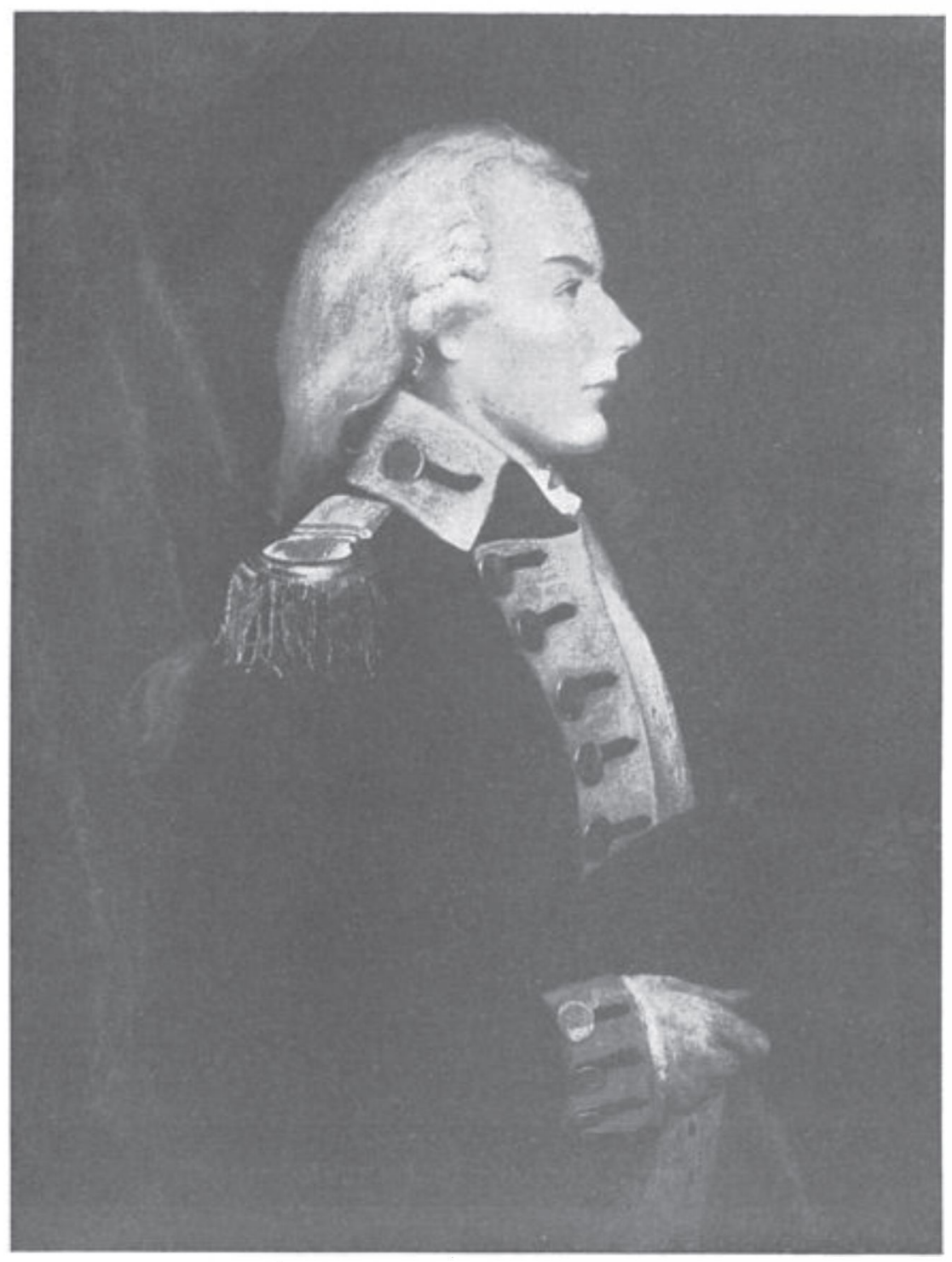

Colonel John Neilson

Salt Merchant of the Revolution and Trustee of Queens College 
specified individuals authority to establish salt works and granted exemption from regular militia service to the labor employed therein. ${ }^{3}$ The results of this legislation were of doubtful value. The majority of the salt works built on the Jersey coast during the Revolution enjoyed no special favors from the state.

In October I 777 the legislature committed New Jersey to a plan for governmental production of salt. This plan, like some of the more modern governmental projects, was very slow in materializing, so slow, in fact, that the act was repealed before anything had been accomplished. The preamble to the repeal bill gave the following explanation: "Whereas the great scarcity of salt in this and the neighboring states induced the legislature to pass an act for purchasing a suitable tract of land [and for] erecting salt works thereon . . . and whereas from various causes the execution of said act hath been delayed; and the great number of private works erecting as well as already erected, promising an ample supply of salt so as to render a public works unnecessary . . . the aforesaid act for creating a public salt works is repealed." 4

By the fall and winter of $1777-1778$ the manufacture of salt was in progress all the way from the Shrewsbury south to Cape May, where shallow and sheltered inlets and coves offered some protection from enemy raids. Boiling houses, huge copper and iron salt pans, pumps, windmills and storehouses bore testimony to the enterprise and resourcefulness of patriot Jerseymen. ${ }^{5}$ American leaders were fully aware of the value of this salt industry to their cause and endeavored to defend the plants from British and Tory raiders bent on their destruction. General Washington, for example, gave General David Forman permission, October 19, 1777, to absent himself and his command from the main army in order

\footnotetext{
${ }^{3}$ The promoters named in the first act (that of October 5, I776), were William Parker, William Corleis, Richard Lippincott, Jeremiah Borden and Lawrence Hartshorne.

1 Act for Erecting Salt Works . . . , passed October 10, 1777. Repealed March 28, I778. See Archives of the State of New Fersey, and Series, Vol. IV, p. 7 .

Archives of the State of New Fersey, 2nd Series, Vol. II, p. I60.
} 
to defend the salt works in Monmouth County, "so truly valuable to the public."'

One of those whose initiative made it unnecessary for New Jersey to establish a public works was Colonel John Neilson of New Brunswick. He, like many another young patriot merchant, found the eight years of the Revolution a time of difficult readjustment. All of his familiar channels of trade were blocked by the beginning of 1776 , and he was forced to resort to new and untried ways of business. ${ }^{7} \mathrm{He}$ formed a partnership in 1777 with Major John Van Emburgh, Captain Jaques Voorhees, and John White, a Philadelphia merchant, to engage in all kinds of business. Privateers were sent out; small ocean-going vessels were purchased and dispatched from Toms River to the French West Indies. Cargoes of goods that were captured and brought to Toms River were bought on the joint accounts of the four partners. Of particular interest was the salt works established by them at Toms River, presumably in I 777 . Colonel Neilson invested no less than $\$ 2,800$ in this salt enterprise between October 10, 1777, and February 16, I778. ${ }^{8}$ Major Van Emburgh assumed charge of the operation of the works at Toms River, but all important decisions were referred by him to Colonel Neilson for final action. John White, in addition to some capital investment, supplied the salt pans or kettles in which the salt water was evaporated.

As a profit-making venture this salt manufactory was a disappointment almost from the start. Too many plants were erected in 1777 on the Jersey coast to be served by the local labor supply. By the beginning of 1778 advertisements began to appear in The New Fersey Gazette offering extraordinary wages to laborers to induce them to come to the salt works

\footnotetext{
6etter from George Washington to David Forman, October 19, 1777. Rutgers University Library MSSS.

${ }^{7}$ To the inconveniences of the blockade were added British occupation of New Brunswick for a time, price fixing by state laws, and the vagaries of printing-press money. According to Colonel Neilson's own calculations, made nearly fifty years afterward, his losses during the Revolution amounted to $\$ 9,200$. Neilson Papers, Vol. I of Selected Papers, MSS. memo.

${ }^{8}$ Neilson Papers, Folder I.
} 
on the shore. ${ }^{9}$ Before the year ended Major Van Emburgh was compelled to suspend operations temporarily because labor could not be had at any wage. In addition to the labor problem, climate, transportation, and fuel supply added to the difficulties of operation.

Major Van Emburgh's correspondence with Colonel Neilson reverted time and again to the numerous annoyances and delays at the Toms River works. "There seems to be no salt making on the Shore scarcely since the Last Alarm of the Enemy's going through the State. People who belonged to the Country has Remained there to Harvest \& the Musquetoes are so excessive Plenty that those belonging to the Shore will not work. Ours has been Idle this 2 weeks but hope to get them going Tomorrow. . . ."10

Five months later, November I8, 1778, the problem of labor supply was again so acute at Toms River that the works were forced to remain idle while Captain Jaques Voorhees scouted the state for laborers. Major Van Emburgh was of the opinion that even if Captain Voorhees succeeded in finding sufficient workers, the price of salt was too low to defray the costs of production.11 The mission of Captain Voorhees proving fruitless, Major Van Emburgh decided to rent the salt-making equipment for six weeks, reserving as rent for the partners one-third of the salt that was produced..$^{12}$ This leasing arrangement was continued thereafter with short intervals of direct operation, until near the close of the Revolution.

The domestic production of salt tided New Jersey over the critical first years of the Revolution. By 1779 imported salt was reaching the New Jersey market in large quantities. Turks Island and Lisbon salt was brought into Barnegat ports by privateers and blockade runners. British vessels laden exclusively with salt were captured and sold in the New Jersey prize courts. ${ }^{13}$

- The New Fersey Gazette, January 7, 1778.

10 Van Emburgh to Neilson, July I2, I 778. Neilson Papers, Folder 4.

11 Van Emburgh to Neilson, November 18, 1778. Neilson Papers, Folder 4.

12 Van Emburgh to Neilson, November 25, 1778 . Neilson Papers, Folder 4.

${ }^{13}$ Archives of the State of New Fersey, 2nd Series, Vol. III, pp. 375, 662, 686. 
Colonel Neilson and his associates played an important part in securing and distributing these irregular imports. They sent out privateers and blockade runners and also purchased supplies of salt brought into Toms River and elsewhere by other ships. They even considered a scheme for bearding the British lion in his own New York den. In November 1778 John White inquired of Colonel Neilson: "I have now to ask you whether it would be possible to get a Man we could trust to go with a few hundred pounds to N.Y. \& purchase a vessell for us load her with salt \& clear her out for Newfoundland \& push into Toms River. . . ."14 Colonel Neilson did not think well of this plan, however, so nothing was done about it.

After the salt had been manufactured or acquired at Toms River it was carted to New Brunswick, Trenton or Philadelphia, depending on the location of the British army, market prices and available transportation. Most of the salt secured by the partners was disposed of by Colonel Neilson or by his order in New Brunswick.

A letter from Anthony White to Colonel Neilson in September 1778 may be used to illustrate not only the importance of salt to New Jersey citizens but also their dependence on Colonel Neilson: "Mr. Patterson informed me in answer to a message I sent you by him about my getting some Salt from you that you were going to the works \& that I might depend upon having some at New Brunswick soon after your return. I have therefore gott the bearer Wm. Silverthorn to go down partly on purpose in order to bring me up some \& have sent by him a Bread barrel ${ }^{\text {ch }}$ I suppose will contain six or seven Bushells \& begg you will have it fill'd \& return'd by him as we are quite out having lived upon the borrow for some time past. . . . If Mr. Neilson should be from home Mrs. Neilson is desired (if she cannot send me the salt) to apply to Mr. Vanimburgh or some other person for some as I cannot do without some at present."15

${ }^{14}$ John White to Neilson, November 16, 1778 . Neilson Papers, Folder 4.

15 Anthony White (at Union) to Neilson, September 24, 1778 . Neilson Papers, Folder 4. 
Many of the salt works on the Jersey coast were being offered for sale in 1779 and $1780,{ }^{16}$ but it was not until 1782 that Colonel Neilson and his associates sold their Toms River plant. Major Van Emburgh had charge of the sale and found as many worries in trying to collect from the purchaser as he had experienced earlier in operating the works. In November I782, he complained to Colonel Neilson: "I do not know when we shall be paid for the Works, I am tired with Dunning. The distress of the shore has prevented my prosecuting but suppose it must end there. . . ."17 This, so far as the records reveal, concluded Colonel Neilson's connection with salt manufacture. He and his associates had produced or procured thousands of bushels of salt during the Revolution. $\mathrm{He}$ and others with a like adaptability to new and trying conditions averted the danger of a salt famine and thereby blasted the British hope of bringing New Jersey to terms by cutting off the supply of this indispensable commodity.

\footnotetext{
${ }^{16}$ See Archives of the State of New Fersey, 2nd Series, Vol. III, pp. 182-3; ibid., Vol. IV, pp. 7,636 .

17 Van Emburgh to Neilson, November 14, 1782. Neilson Papers, Folder 5.
} 